\title{
Economic Empowerment Program for the Wives of Ex Convicted Terrorists as a Deradicalization Effort in Indonesia
}

\author{
Aysha Rizki Ramadhyas ${ }^{1}$, Muhamad Syauqillah ${ }^{2}$, Jerry Marcellinus Logahan ${ }^{3}$ \\ \{aysha.rizki@ui.ac.id ${ }^{1}$, muhamadsyauqillah@ui.ac.id ${ }^{2}$, jerrymarcellinus59@gmail.com ${ }^{3}$ \} \\ ${ }^{1,2,3}$ Terrorism Studies, School of Strategic and Global Studies-Universitas Indonesia
}

\begin{abstract}
The research on the economic empowerment program for the wives of ex convicted terrorists in Indonesia is considerably scarce. Consequently, economic empowerment is necessary to be implemented as deradicalization effort for ex-terrorist prisoners' families besides the one for the perpetrator or former perpetrators of criminal terrorism acts. Economic empowerment which is carried out by the National Counterterrorism Agency of Indonesia (BNPT) mostly tends to focus on the perpetrators (convicted terrorists) and former perpetrators (ex-convicted terrorists), whereas the families, especially the wives of ex convicted terrorists have significant roles in supporting their family's financial condition while their husbands are being imprisoned. This study aims to explore the implementation of an economic empowerment program for the wives of ex convicted terrorists and to explore the improvements needed to maximize economic empowerment programs for the wives of ex convicted terrorists. It also utilizes a qualitative method with the approach of literature study and interviews. The result shows that genderbased economic empowerment is crucial to be done, encouraging wives to master useful skills and to be independent. They also create prosperity so that they will not be engaged in radical-terrorism groups.
\end{abstract}

Keywords: Empowerment, Ex Convicted Terrorists’ Families, Deradicalization

\section{Introduction}

When their husbands are serving their time in prison, the wives of ex convicted terrorists lose the breadwinners of their families. During their vulnerable stage, terrorist groups would jump at the chance to give them financial support. This financial support would then prompt the wives to feel obligated to return the favor. This scheme is a common strategy made by terrorist groups to gather the wives of ex convicted terrorists or former terrorists. It aims to secure their loyalty to the groups. Consequently, the wives would then be radicalized and be willing to join and support the groups. In regards to this situation, the government should push a full effort to support the wives of ex convicted terrorists in their times of need not only as an ideology removal attempt but also as an effort to help the family of convicts and convicted terrorists.

Umi Naufa, a teacher from Al - Islam Religious Education Site (TPA) in Lamongan, is the wife of ex convicted terrorist Agus Martin or Hasan or Abu Naufa who was involved in a terrorism case in 2013. Umi Naufa has three children, Naufa, AS, and IN. During the interview process, she described her condition before and after her husband was being detained by The National's Police, Special Detachment 88, due to his involvement in the terrorist group $A l$ - 
Jamaah Al-Islamiyah. After her husband's detainment, she had to be the breadwinner of the family. She said this period of change was a defining phase for the wife of an ex convicted terrorist to decide whether or not she should join her husband's terrorist group. The haunting disappointment in the law enforcement officer for the way they had treated her husband would soon enough turn into hatred, which eventually turned them to choose the terrorist group's side. As a result, to prevent the wives from joining this radical-terrorist group, an economic empowerment program remains significant.

Research on the economic empowerment program for the wives of ex convicted terrorists in Indonesia is considerably scarce. The researches in Indonesia tend to focus on deradicalization effort for ex-convicted terrorists as reported in the Mapping and Evaluating Deradicalization and Disengagement in Indonesia. The report shows that the counterterrorism effort in the country still revolves around the attempt to transform the ideology and the attitude of ex convicted terrorists as well as other convicts through soft approaches [1], and it has not involved yet the wives of ex convicted terrorists. Meanwhile, in reality, the wives could play a significant role in influencing their husbands to refrain from supporting terrorism acts once their serving time is up. Embracing the wives could be a harmless effort to rehabilitate the convicted terrorists. However, the initiative has yet to become the government's priority up until now.

Besides standing by their husbands' side, the wives of ex convicted terrorists could also potentially commit a terrorist act. Sidney Jones stated that there was a 40 to 50 percent increase in the involvement of women and children in terrorism acts, especially after many Indonesian citizens (WNI) who were suspected to go to Syria through Turkey were repatriated [2]. Through this event, it shows that there is a need for a deradicalization program to include not only men but also women. The summary of Georgetown Institute Women, Deradicalization, and Rehabilitation: Lessons from an Expert Workshop proclaimed that the lack of awareness in the governmental institutions to provide a gender-based deradicalization program for women would result from an enormous consequence [3]. This consequence would, among others, turn their husbands to be recidivists in the same terrorism act who enforce their wives to commit the same actions.

According to Susilo, the culture of violence, war, and military is identified with masculine men who are expected to be protective, responsible, independent, confident, fierce, and many others [4]. However, this phenomenon shows that there is a distortion in the gender discourse itself. In Indonesia, in May 2018, according to The National Police spokesperson Brig. Gen. M. Iqbal, there were two women, namely Siska Amalia and Siska Nur Azizah, who became terrorism suspects [5]. The two women attempted to sneak into Mako Brimob in Kelapa Dua, Depok, to attack officers as a form of their fight and faith in what was believed to be ISIS. Women's involvement in terrorism act does not only take place in Indonesia; it also occurred in Sri Lanka, among others. In Sri Lanka, women's involvement in acts of terrorism is demonstrated by the presence of Liberation Tigers of Tamil Eelam (LTTE). This group aims to fight against the oppressive nation by teaching women to fight armed and unarmed and by introducing them to war strategy just like what men mostly do.

There are push factors to explain the involvement of women in terrorist groups. Some of them fight in the name of religious faith, disappointment in the government, marginalization or discriminatory acts from other groups, and also economic factor. Laure explained that these accumulated disappointments became the basis of ISIS to provoke them to join the terrorist group. Besides the push factors mentioned above, the success of terrorist groups like ISIS and its propaganda also become the main factor as to why women are adamant about joining in. A considerable part of ISIS propaganda comes in the form of social media content in which jihad and hijra are significantly becoming an obligation for Muslims and in which a guarantee of a 
better life in Syria, equality, and empowerment are promised. These contents show that women are promised a chance to be equal to men as what women members in ISIS are like in the US [6] Consequently, many wooed women and children decide to migrate to Syria to join ISIS. This supporting factor encourages women to use their masculine side to express violence.

Women tend to carry feminine traits such as being gentle, affectionate, caring, and many others. However, terrorist groups like to utilize the underlying, never-before-seen features within them to ensure the continuity of their groups. The feminine label soon inevitably turns into advantages for groups like ISIS and Boko Haram. These groups shared their propaganda by actively encouraging women to take on a crucial role in life in the name of faith. This effort soon manages to gather women to join the groups. The two groups have succeeded in utilizing gender bias and avoiding suspicions of their nation in identifying terrorist acts.

Women tend to play a passive role in a terrorist group, one of them being a means to radicalize their children. The radicalization process can be done through teachings in their homes or schools, and by spreading perspectives deemed to be the absolute truth by the group. Spencer divided three primary roles of women in a radicalization process, namely: 1) Domestic part, that is, women as mothers and wives would be necessary to transmit and instill the radical ideology into their children. 2) Operational role, that is with which women actively participate in recruiting group or an individual to join the terrorist group. 3) National development key, which is how women are, in fact, the potential asset that can contribute to a nation's development in economy, education, and social [6].

Looking on the phenomenon described above, it believes that women can inherently be the supporting factor in helping their husband's spreading their radical ideology or even influencing them to commit their old offends. As a result, Indonesia needs a deradicalization program that can be used to embrace the wives of ex convicted terrorists as a means to help the government lower the number of terrorist acts in the country. This research attempts to dismantle the underlying factors that cause the scarcity of economic empowerment programs for the wives of ex convicted terrorists as a deradicalization effort through qualitative method and literary study as well as interview. The authors' hypothesis is that gender-based economic empowerment program is crucial in helping the wives of ex-terrorists to become independent and creative and in establishing welfare so that they will opt to return to radical terrorist groups.

\section{Conceptual Framework}

\subsection{Terrorism and Radicalism}

The understanding of terrorism can be closely associated with the use of violence and fear method spread by an individual or a group that aims to threaten their government (nation) and its society to achieve a spesific goal. Terrorism comes from the word Terrace, which means shudder and Deterrere, that means fear. Conceptually, the United Nations (UN) stated that terrorism is a criminal conduct committed by creating terror amongst the society to give pressure to the country [7].

The author breaks down several factors that can be the basis of terrorist acts, namely, (1) Dissatisfaction with the government or the current political condition, (2) poverty and welfare. The author believes that the distortion in job opportunities contributes to the increasing criminality. The government's inability to accommodate the society can be the indicator of an individual or a group to commit terrorist acts. 
Radicalism is the most influential factor that contributes to an individual joining terrorism. Radicalism is known as a concept upheld by an individual or a group to actualize a specific goal through violence. Often, radicalism is related to a religious belief. Religious radicalism can be seen through fanaticism towards a religion, excessive collective excitement, intolerance towards others, and tend to use violence to solve a problem [7]. This concept is used to understand the underlying factor for an individual to commit a terrorist act so that it can help bring forth an onpoint, effective deradicalization program.

Radicalism becomes a crucial component in the support for the success of deradicalization program. International Peace Institute (2010) firm that the radicalization process of an individual or a group is important to be understood, and the Internet has become one of the contributing factors of "self-radicalization." According to the survey conducted by author, there are indicators that enable an individual to be exposed to radicalism; (1) the strong belief of an individual on radicalism groups who uphold the same kind of excessive religious belief , (2) desperation, (3) naivety, (4) financial issue [8].

\subsection{Family's Role in Radicalism}

The involvement of women and children in terrorism experienced an increase, which indicates that family members are the key in the recruiting process of an individual or a terrorist group. A research by Harris Hogan in 2014 [9] revealed that family has the leading role in the development of radicalism, as well as its prevention by providing an accommodating environment. Some of the contributing factors are namely inadequate nurturing, the nonexistent, or lack of role models. Besides, a parent can knowingly teach their children radical beliefs through the support of other fundamental individuals and acts in society.

Family can also become the guardian of the development of radical beliefs; however, the research on this issue is still relatively scarce [9]. Another study by Riany et al., (2018) found that parents with radical beliefs hold on to the fundamental Islam faith and uphold this ideology as their principles. The parents would then actively teach their children in the hope that they would apply the practice of Islamic values in their literal sense and as the only essential aspects for their children [9]. As a comparison, parents with moderate Islam faith would focus their teachings on the strengthening of religious values, social norms, and cultures besides Islam. To these Islam reasonable parents, teaching their children about social competition would be an effective strategy to develop the endurance of their children in confronting many kinds of belief in the society [9].

The research of Riany et al. (2018) also discovered several factors used in spreading radical doctrine in youth such as socio-political issues and injustice against Muslims through the media. According to a participant who is a former extremist, the doctrine about prejudice against Muslims is the first step in instilling radical beliefs in youth. The next step would be schools that would force the child to commit jihad through intensive lessons about radicalism. These former participants also revealed that establishing radical doctrines would succeed for adolescents who have family issues, such as lousy relationships with parents, the lack of foundation in the family, the absence of role models, and the lack of parents' supervision [9]. Besides family factors, the lack of understanding in comprehensive Islam also contributes as a defining factor in the spread of radicalism. 


\subsection{Women in Terrorism}

In terrorism, men are much more likely to be to be perpetrators and women victims; however, women have become the supporting fighter behind the acts. Banks (2019) said that the reason why women were involved in terrorist acts in Palestine was mainly because of the country's patriarchal culture that allowed manipulations done by men against the dignity of women. This perspective is echoed by Bloom in Banks (2019), who wrote in his book Bombshell: Women and Terrorism that Palestine women enjoyed the freedom that had when they committed terrorist acts. Besides, the supporters of women empowerment and equality believed that the authority of their religion nowadays had managed to turn women into syahidas, a status previously reserved only for men. This situation shows that by becoming the actor of terrorist act, women can achieve a condition in society[10].

The male stereotype in terrorism; such as male dominance in the family has become one of the reasons women involved in terrorism. The enticement used by men to recruit potential women mostly carries the discourse of gender equality, the promise of security for women who have violated gender norms and been alienated by the society, revenge for loved ones who died in the acts of terrorism and the religious advantages [10] For example, the militant organization Hamas promised women that they would be reunited with their husbands in heaven as a prize for their commitment to jihad [10].

Several researches showed that the strategic advantages that are expected by the leader of terrorist groups if women are involved in their actions include more prolonged attention from the media, more significant sympathy, the increase of fear, and the advertisement for women recruitment [10]. On the other hand, the prejudice against women often enables women to go through security devices more smoothly than men, and the fact women seldom become leaders would mean that their deaths or captivity would not cost their group a massive loss.

Ruth Gan and other fellow researchers in Banks (2019) attempted to analyze the Surabaya bombing case by doing a study on 30 cases of women who were inspired by ISIS between the years 2013 to 2018. This research showed that there was a gender shift in terrorism. It affects a certain specific gender such as women as mothers who always take care of children and household chores. Yet, women can be a key in terrorism; not only to transmit the doctrine of jihad to their children but also play an active role with their husband as suicide bomber. [10]. Using ISIS manifesto as a source, the author revealed that the justification of ISIS in Surabaya attacks was the evolution of jihadists.

\subsection{Disengagement and Deradicalization}

Fink \& Hearne (2008) revealed that disengagement refers to the changing of attitude of terrorism actors like what they experienced when they changed their roles or quit their groups. However, disengagement is believed not to change the values upheld by those terrorist group members. Meanwhile, deradicalization is the underlying cognitive alteration, that is, the shifting of values owned by terrorist group members to become not radical. There are factors contributing to terrorist disengagement, such as social groups or family, frustration over the leadership in their groups, and the desire to live normally without conflict [11]. Disengagement often becomes the first step of deradicalization, which then would be started with cognitive opening; an individual's openness for new ideas and values that are different from what they previously believed.

Deradicalization is a neutralization process of someone to change the radical-terrorism belief into non-radical belief, and it is not limited to the changing of attitude only [12] 
Deradicalization is an effort to transform radical belief, ideology, and philosophy with a multi and interdisciplinary approach. In the study of terrorism, deradicalization is the critical explanation of the cause-effect occurring in the terrorism concept. Deradicalization is started with identifying the tendency of an individual when faced with radicalization, which then would be used as a program that would enable them to fight against radicalization. The assumption surrounding the establishment of the program is about how radicalization is closely related to terrorism and violence, and deradicalization is created to prevent recidivism for terrorism offenders [13]. It is essential to understand the concept of deradicalization in terms of analyzing the significant change of attitude and cognitive of the ex-convicted terrorists.

The critical point in deradicalization is to know the motivation of the terrorist group members, whether it revolves around economy, social, or psychological. Another point is to empower the family and the spouse to persuade their loved ones to leave the group. This program should focus on giving financial incentives and social support to deradicalized terrorist group members. Last, disengaging the ex-convicted and their family members from terrorist networks by reducing the frequency of their interaction. This can also minimize the threat of radicalization posed by terrorist groups in the near future.

A research conducted by Hwang (2017) about the disengagement of militant jihadis in Indonesia succeeded in identifying four main themes adopted by jihadis to disengage themselves from the group; 1). disappointment on the leadership, 2). the awareness of disadvantages in joining terrorist groups, 3). the need to develop new relations, and 4). the shifting of life goals such as continuing education, starting a family or fulfilling the needs of family[14]. Barelle (2015), in his research, attempted to find a new finding related to individual discharge from extremist violence in the Western context. This research tried to figure out why and how an individual could leave extremism, how they could reconnect, and what life aspects may change. The research used transcripts of 22 interviews with ex-extremists from diverse backgrounds through IPA. This article aimed to create a conceptualization of disengagement called the Pro-Integration Model (PIM) [15].

The article began with a discussion about what people are not aware of in regards to disengagement and extremist violence. Bjorg revealed that many individuals who joined the groups would eventually leave the groups because they have not an understanding as to how or why these members could leave extremism or what caused them to go directly and voluntarily instead of being postponed and forced [15]. Their disengagement may have included 'total disengagement from social norms, values, attitude, relations and connectivity' [15].

Learning about community-based reintegration models can help improve the deradicalization program for ex convicted terrorists. Deradicalization with a humanist approach is expected to be able to release extremist individuals or groups from violence. In this study, the genuine involvement of the community is the key that enables radical terrorist individuals or groups to continue living or make progress in their goals and beliefs in a non-violent manner.

\subsection{Women Deradicalization}

This study outlines the lack of a gender-based terrorism prevention program. Women have a very significant role in supporting the understanding of radicalism and terrorism. Forms of women's participation in terrorism are divided into intelligence data collection, recruitment, provision of health services, safe houses, acts of violence, suicide bombing. Statistics from the year 1985 to 2010 show that there were 257 women in the world involved in the explosion. As in the research, will be explained that the factors driving women involved in radicalism and 
terrorism consist of; feelings of disappointment or marginalization, low levels of education, and inadequate environmental conditions.

Carter (2013), in his research, emphasizes the importance of involving women in the process of combating terrorism. For example, a community-based approach to women can win the hearts of marginalized communities to reduce their potential to join terrorist radicalism groups. There are also interventions carried out in preventing women from being exposed to radicalism through an empowerment program, one of which is Sisters against Violent Extremism (SAVE), Mothers for Change! initiated by Women without Borders in 2008 [16]. Campaigns or socialization are carried out to encourage and strengthen the strongholds of women to fight the ideology of violent extremism.

Research conducted by Ortbals \& Poloni-Staudiner (2018) revealed that America has a soft approach named "security feminism" with an agenda to promote women's rights as ambassadors of counter-terrorism and national security. This approach is very closely related to Hillary Clinton's doctrine, which states that the empowerment of women and girls can improve state security in certain countries, which, therefore can stabilize the world and foreign interests. He cited the killings of women to cause the international society to end gender and feminine inequality, which is dangerous for women. Another example is when countries value boys more than girls, which causes the ratio of men to increase and never marry. Thus, achieving stability requires an awareness that women and men are equal [17].

The same thing can also be applied to counterterrorism efforts today. The peace of a country depends on the state's treatment of women, especially violence against women. Researchers reveal that many individual terrorists have a history of being perpetrators of gender violence in the past and other types of violence targeting women. In addition to security feminism that was formed to fight terrorism, Los Angeles has also made a pilot program "engagement efforts with women" that tend to succeed in gender-based deradicalization efforts [17].

Ortbals \& Poloni-Staudiner (2018) added that when the United States tried to emphasize the improvement of women's rights and take advantage of the role of mothers, there was a program in Morocco called "murshidat" which highlighted how women could moderate interpretations of Islamic teachings. The Murshidat Program is seen not only as a success in combating terrorism, but also as a way to change the role of women. If women are changed, it believes that Islam will change for the better. Murshidat has become a religious authority and community figure that promotes Islam as a peaceful faith. Traditionally, Islam has separated sacred spaces between women and men [17]. Therefore, Moroccan women do not take the role of leading spiritual leadership. The creation of Murshidat, on the other hand, shows that the king and the state are actively seeking to educate women and change the stereotype that women cannot influence men in religion.

Indonesia has traditionally focused on men as the target of deradicalization. However, in 2015, Indonesia started a program called, "Entrepreneurship Empowerment Program," which seeks to train and advise the wives of ex convicted terrorists [18]. A former terrorist, Ali Fauzi explained the purpose of the program is to prepare women economically and psychologically before reuniting with their husbands. He revealed that women are part of counterterrorism because they are a missing link in rehabilitation, so that when militant jihadists complete punishment, they need others in their lives to become positive forces [18]. Varagur (2017) adds that wives need careful preparation before dealing with their recently freed husbands, and need to be empowered because their families face stigma due to their husband's actions [18]. 


\section{Research Method}

This research is qualitative research using a phenomenological approach. Phenomenology explains the meaning of individuals regarding their life experiences as a concept or phenomenon [19]. Phenomenology research aims to describe the experience of individuals with the phenomena they experience, so that people can undertand certain phenomena. This study uses data mining stages, namely: thematizing, designing, interviewing, transcribing, analyzing, verifying, and reporting.

Before conducting interviews, participants would receive an explanation surrounding the general idea of the research and the interview process. Next, the participant would then be asked to sign informed consent as an agreement to participate in the study. The researcher records the interview with a recording app on a smartphone and an iPod. After that, the researcher would then do verbatim writing with Ms. Words before continuing to the data analysis process.

The research participant is 1 (one) woman who is the wife of an ex convicted terrorist who was involved in several different cases. At the moment, Umi Naufa (not her real name) is a teacher in a Religious Education Site (TPA). Based on the results of the interview, her husband Agus Martin alias Hasan alias Abu Naufa was arrested in 2014 for storing a type of revolver with 6 (six) bullets. Agus Martin is one of the ex convicted terrorists affiliated with the $A l$ Jamaah Al-Islamiyah (JI) group [20].

\section{Result and Discussion}

The wife of an ex convicted terrorist is a figure in a family who is vulnerable to radical terrorism and often plays a essential role in transmitting the understanding of jihad to her children. Elizabeth Foley [21] explained that one of the factors that supported women joining ISIS groups was political factors, namely poverty. The low level of the economy gives rise to feelings of marginalization so that many women choose to join the radical terrorism group and carry out acts of violence. Therefore, a program that aims to increase the skills and expertise of individuals or groups that are indicated or exposed to radical terrorism.

\subsection{Deradicalization Program in Indonesia}

The National Counterterrorism Agency (BNPT) was formed in 2010, after the bombing tragedy at the JW Marriott and Ritz-Carlton in 2009 [22]. This institution engages in three focuses, namely: 1) Prevention, protection, and deradicalization, 2) Operations and enforcement, and 3) International cooperation. Referring to the BNPT Blueprint (2015), the BNPT "is expected to function as a guide for all institutions involved in the prevention and control of radical understanding" in Indonesia. The Blueprint of BNPT defines deradicalization as "any effort to change radical beliefs or ideologies into non-radicals, with a multi and interdisciplinary approach". The program consists of four stages, "Identification, rehabilitation, reeducation, and reintegration" [23]. Identification involves interviewing prisoners to determine their level of involvement, ideological understanding, and affiliation. The rehabilitation and reeducation phase consists of ideological moderation carried out through dialogue and persuasive approaches. Also, the reintegration phase is an attempt to prepare terrorist prisoners to return to the community. 
Besides that, BNPT also has a deradicalization program for the ex convicted terrorists and their family members, which consists of four stages: "identification and assessment, religious coaching program, fostering national insight program, and economic independence program" [23]. The deradicalization program outside of prison has several targets, including ex-terrorists and ex convicted terrorists, families, networks, and potentially radical people or groups. The family refers to the closest person who has blood relations, kinship, or marriage, such as: parents, in-laws, sons-in-law, wives, children, siblings, and brothers or sisters-in-law. The identification and assessment phase aims to find out and determine the identity of former terrorists, families, networks, and people or groups who are being exposed to radicalism. Meanwhile, religious coaching program seeks to sensitize the orientation of a fundamental ideology of violence to an ideology orientation that is inclusive, peaceful, and tolerant. The development of a nationalist vision aims to raise awareness of a radical ideological orientation into an inclusive national direction. In addition to these three stages, there are stages of fostering economic independence that are the focus of this research.

Fostering economic independence is an effort given to former terrorists, families, networks, and people or groups that are indicated radically to provide practical skills in entrepreneurship [23]. Practical skills presented in this program are expected to be a provision of skills to be used as work for program objectives. The types of skills will be adjusted to the interests, talents, potentials, and availability of resources and markets in the area or around the place of residence surrounding the target of these economic independence development programs.

The provision of these skills is expected to make the programs' target to be an independent individual or family. The program is also expected to improve their skills and capacity in creating their own business. Besides aiming to increase the capacity of individuals in entrepreneurship. This program is known as a soft approach strategy by embracing terrorist families, especially the wives to not join radical groups. With this program, the wife can have the skills and the capital that can be used to support the family, without requiring a helping hand from the husband's terrorist organization.

Even though the economic empowerment program has a useful purpose, the application of this program needs a lot of improvement. Sumpter, in his research, related to fighting terrorism in Indonesia, states that there are facts that reveal that the BNPT has not optimally fullfilled the need of ex convicted terrorists regarding financial support and employment opportunities after the ex convicted terrorists released from the prison. This effect will eventually lead to resentment and distrust of ex convicted terrorists in the government. Also, ex-convicted who were released said that they saw the BNPT as an "ATM," so they tended to join the program only to get personal benefits [22].

Umi Naufa is the wife of ex-convicted terrorists. Before her husband was arrested by the National Police's, Special Detachment of 88 due to the involvement in terrorist organization, Umi Naufa claimed not to know about her husband's activities in his terrorist group. She and her family were not actively or passively involved in the husband's radicalization process. Umi Naufa has moderate islamic outlook, therefore she decided Umi Naufa to join the women deradicalization program. She wants to contribute in helping the process of deradicalizing her husband.

Umi Naufa revealed that after her husband was arrested by Special Detachment 88, she became the backbone of her family. Also, Umi Naufa also still has the responsibility to provide for her three children. Seeing these conditions, Umi Naufa's husband decided to join the terrorist group no longer. It shows that the family played a vital role in the process of deradicalization of the husband. However, this study shows new findings that low-income family financial conditions and sympathy for abandoned family members can be a reason for someone to break 
away from a terrorist group. From the narrative, it appears that women and family financial conditions play an essential role in the efforts of deradicalization.

In 2017, Umi Naufa joined the economic empowerment program carried out by the BNPT. The program aims to provide practical skills in entrepreneurship. Practical skills presented in this program are expected to be a provision of skills that can be used to fulfill the program's objectives. Umi Naufa admitted that the program has helped her family to make a living after losing the head of their family.

The provision of skills in the economic empowerment program also aims to make the program targets to become independent. Umi Naufa believed that the economic empowerment program has made her more skilled and independent, as well as helped her in creating family welfare not to get caught up in radical-terrorism groups anymore. Research by Ferguson, N. (2016) says that financial assistance is crucial in supporting a more optimal reintegration process [24]. In addition to increasing welfare, economic assistance attempts to minimize the influence of radical terrorist groups. Seeing the positive impact felt by Umi Naufa, the deradicalization program made explicitly made for the wife or partner of ex-convicted terrorists needs to be carried out. This effort is a soft approach to embrace the families of ex convicted terrorists, mainly to prevent them from joining the radical groups.

Although the economic empowerment program has a useful purpose, the application of the program requires a lot of improvement. Umi Naufa revealed that the economic empowerment program had not accompanied with skills development program. She added that she got money as business capital and business building skills, but she had not yet gotten other more specific skills, such as marketing strategies. She also revealed that the skills development program based on the abilities of each individual had not been conducted. Sukabdi [24]explained that the economic assistance program as a deradicalization effort needs to be adjusted to the abilities and interests of each individual. Besides that, ensuring the sustainability of economic assistance program is also a key to make deradicalization more effective .

In addition to skills that have not yet been obtained, Umi Naufa also revealed that she felt that there were deficiencies in the BNPT program she joined some time ago, precisely in 2018. Although she had joined the program, she revealed that this program was only held in a concise manner.. Umi Naufa expressed her hope that BNPT could make skills training in each district or city more accessible to all program targets. Referring to the many benefits obtained by Umi Naufa, women's empowerment programs are effective in helping their husbands who are in prison by alleviating the financial burden on the family. With evaluations to improve the effects of deradicalization, this soft approach program can be a useful step to help families escape from the bondage of terrorist groups.

\section{Conclusion and Recommendation}

Women play a strong role in deradicalization program. Women can convince their husbands about the negative impact of depending on terrorist groups for their own family. Referring to the above, we need an economic empowerment program for women whose husbands are ex convicted terrorists. It helps the wives of ex convicted terrorists in order to achieve financial independence so that they will not be dependent on terrorist groups.

The results revealed that participant revealed that gender-based economic empowerment was an important thing to do. This can be seen from participant who revealed that economic empowerment really helped their families to make a living after losing their husband as head of 
the family. With economic empowerment, the wife also becomes skilled and independent, and increases family welfare so as not to get caught up in radical-terrorism groups.

Nevertheless, existing economic-based empowerment programs also need to be evaluated. Some evaluations submitted by participants include skills training, more affordable training locations, more ongoing training, and open counseling to entrepreneurs when the program targets experience obstacles. With these improvements, it is expected that the BNPT can become the frontline in embracing the families of ex convicted terrorists, especially the wives who have a significant role in fostering radicalism or deradicalization for their husbands who are involved in terrorism cases in the past.

\section{References}

[1] Hiariej, E., \& et.al. (2015). Mapping \& evaluating de-radicalization and disengagement programs in Indonesia. Jakarta: Indonesia Institute for Social Empowerment

[2] Kompas.com. (2015, 11 26). Sidney Jones: Indonesia Perlu Buat Program Deradikalisasi Khusus Perempuan dan Anak Artikel ini telah tayang di Kompas.com dengan judul "Sidney Jones: Indonesia Perlu Buat Program Deradikalisasi Khusus Perempuan dan Anak", https://nasional.kompas.com/rea. Retrieved from Kompas.com: https://nasional.kompas.com/read/2015/11/26/16451071/Sidney.Jones.Indonesia.Perlu

[3] Turkington, R., \& Christien, A. (2018). Women, Deradicalization and Rehabilitation; Lesson from an Expert Workshop. Georgetown Institute for Women, Peace and Security.

[4] Susilo, A. G. (2015). Perempuan dan Narasi Kekerasan: Studi Kritis Peran Gender Dalam Deradikalisasi. Teosofi: Jurnal Tasawuf dan Pemikiran Islam, 432-454.

[5] Liputan6.com. (2018, 05 16). Kisah Terduga Teroris Perempuan yang Nyaris Menyerang Rutan Mako Brimob. Retrieved from Liputan.com.Buat.Program.Deradikalisasi.Khusus.Perempuan.dan.Anak?page=2

[6] Shapiro, L. R., \& Maras, M.-H. (2018). Women's Radicalization to Religious Terrorism: An Examination of ISIS Cases in the United States. Studies in Conflict \& Terrorism, 7.

[7] Sinaga, Obstarar., Ramelan, Prayitno., \& Monatratama, Ian. (2018). Terorisme kanan di Indonesia: Dinamika dan penanggulangannya. Jakarta: Elex Media Komputindo.

[8] International Peace Institute (2010)

[9] Riany, Yuliana Eva., Haslam, Divna., Musyafak, Najahan., Farida, Jauharotul., Ma'arif, Syamsul., \& Sanders, Matthew. (2018). Understanding the role of parenting in developing radical beliefs: Lessons learned from Indonesia. Security Journal.

[10] Banks, Cyndi. (2019). Introduction: Women, Gender, and Terrorism: Gendering Terrorism. Women \& Criminal Justice, DOI: 10.1080/08974454.2019.1633612.

[11] Fink, Naureen. C \& Hearne, Ellie. B. (2008). Beyond Terrorism: Deradicalization and Disengagement from Violent Extremism. International Peace Institute.

[12] Rabasa, Angel. S. L. (2010). Deradicalizing Islamist Extremist. RAND Corporation.

[13] Lynch, C. J. (2017). "Doing Peace": The Role of Ex-Political Prisoners in Violence Prevention Initiatives in Northern Ireland. Studies in Conflict \& Terrorism, 1-20.

[14] Hwang, Julie Chernov. (207). The disengagement of Indonesian jihadists: Understanding the pathways. Terrorism and Political Violence, Vol 23, 277-295. DOI: 10.1080/09546553.2015.1034855. [15] Barelle, Kate (2015). Pro - integration: disengagement from and life after extremism. Behavioral Science of Terrorism and Political Aggression, 129-142.

[16] Carter, Becky. (2013). Women and Violent Extremism. Governance, Social Development, Humanitarian and Conflict.

[17] Orbals, C.D., \& Poloni-Staudiner, L.M. (2018). Gender and Counter-terrorism. Gender and Political Violence, 273-315. DOI: 10.1007/978-3-319-73628-0_10. 
[18] Varagur, K. (2017). Empowering women to break the Jihadi cycle. The New York Times. https:// www.nytimes.com/2017/06/20/opinion/empowering-women-to-break-the- jihadi-cycle.html. Accessed 5 August 2019.

[19] Creswell, J. (2007). Qualitative inquiry \& research design: choosing among five approaches, 2nd ed. California: Sage Publication.

[20] Decision of the Supreme Court, 2014

[21] Taskarina, Leebarty. (2019). Istri Teroris Korban yang Terlupakan: Kisah Perempuan dalam Kejahatan Terorisme. Jakarta: Elex Media Komputindo

[22] Sumpter, Cameron. (2017). Countering violent extremism in Indonesia: priorities, practice and the role of civil society. Journal of Deradicalization, 11.

[23] Badan Nasional Penanggulangan Teroris. (2015). Blueprint Deradikalisasi. Jakarta.

[24] Ferguson, Neil. (2016). Disengaging from Terrorism: A Northern Irish Experience. Journal for Deradicalization. 